\title{
Ucieczka z poetyki
}

ABSTRACT. Krajewska Anna, Ucieczka z poetyki [Escape from poetics]. „Przestrzenie Teorii” 26. Poznań 2016, Adam Mickiewicz University Press, pp. 7-10. ISSN 1644-6763. DOI 10.14746/ pt.2016.26.0.

Editorial dedicated to the memory of Stanisław Barańczak.

Nasza pamięć jest złudna, zawsze subiektywna, jednostkowa, nie ogarnia całości, żywi się obrazami.

Pamiętam - ćwiczenia z poetyki w Collegium Novum. Magister Stanisław Barańczak - mówiąc jak zwykle ciekawie i niewyraźnie - pokazywał nam, studentom drugiego roku polonistyki, sposób zaczynania przez Zbigniewa Herberta wierszy o fabułach wziętych z mitu. Mit się kończył - wiersz się zaczynał. Zwycięstwo już zostało przyznane Apollinowi, ale muzyka prawdziwa dopiero miała się zrodzić z krzyku Marsjasza. Od śmierci Poety przyglądam się wszystkim uroczystościom, słucham okolicznościowych przemówień, czytam teksty o Nim - mit potężnieje (mural, pasaż, film, spektakl teatralny, nagroda Jego imienia...). Porządek mitu pozostanie niewzruszony, ale prawda poezji narastać będzie już po nim, gdy wybrzmią wszystkie gesty i zblakną rocznice, gdy w ciszy poczujemy nagle potrzebę sięgnięcia po Jego wiersze.

Pamiętam - zajęcia z teorii literatury. Doktor Stanisław Barańczak tłumaczy skomplikowane relacje osobowe w literaturze, pokazuje - w duchu strukturalizmu - rozbieżność między autorem, autorem wewnętrznym, podmiotem czynności twórczych. Uciekamy z zajęć... Zostajemy złapani i przykładnie ukarani - odrabiamy zajęcia, na które musimy przeczytać jakiegoś Bułhakowa... Dyskusję o Mistrzu i Małgorzacie zapamiętujemy „na całe życie”.

Pamiętam - zgrzyt siedemnastki na rogu Mielżyńskiego i Fredry zanim przeczytam w wierszu: „a siedemnastka wlecze swój ciemnozielony zgrzyt / po przeciwbieżnym łuku szyn za róg Mielżyńskiego i Fredry”. Tam spotykamy się często ze Staszkiem w drodze na zebranie Zakładu Teorii Literatury prowadzone przez Profesora Jerzego Ziomka. Stanisław pisze ukradkiem na serwetkach wiersze, ja przygotowuję swoje pierwsze zajęcia $\mathrm{z}$ teorii literatury na temat „relacji osobowych”...

Pamiętam - przyjazd Poety do Poznania i tłumy, które przyszły na wykład z teorii i praktyki przekładu. Z koleżankami i kolegami z naszej dawnej grupy studenckiej, dziś już wykładowcami, szepczemy ze wstydem - „a myśmy uciekali Mu z poetyki...”. Staszek podchodzi do nas, wita się tak serdecznie, jakby to była tylko chwila, by pokonać „rozsuwające się kontynenty”, wtedy, gdy „ziemia usuwała się spod nóg”. Nazajutrz

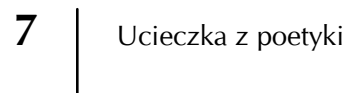


studenci pytają mnie, czy rzeczywiście wyjeżdżając, trzymał wiązankę „więdnących dalii / na pożegnanie wręczonych"? Widać nie było ich na zajęciach z poetyki...

Można uciec z poetyki, ale nie wolno porzucać poezji. Stanisław myślał wierszami, choć, odnoszę dziś takie wrażenie, że sam stale „uciekał z poetyki" (nie z zajęć rzecz jasna, ale z pewnych pancerzy stylu, konwencji, odbioru). Strukturalizm uwodził, ale i więził. Uciekał więc z poetyki, ale nigdy nie porzucał wiersza. Opozycje binarne (choćby te najłatwiej zauważalne w tytułach: Nieufni $i$ zadufani, Etyka i poetyka, Ironia $i$ harmonia...) nie wytrzymywały jednak naporu myśli wiążącej sprzeczności, zacierającej granice, prowadzącej do ujęć metafizycznych i do absurdalnego humoru. Mało tego - do historii przeszły słynne definicje antybinarne Barańczaka, jak np.: „nonsensista to śmieszniejszy poeta metafizyczny". Stanisław badał mechanizm myślenia w kategoriach dualizmu $\mathrm{i}$ - w moim odczuciu - od początku się w nim nie mieścił (bawił się sztywną formą, łamał ją, pokazywał zarazem jej kunszt, jak i absurd). Takie dzielenie, które zwykle jest synonimem dydaktycznego porządkowania, sprawiało, że był znakomitym nauczycielem akademickim, ale to samo dzielenie, w wymiarze poezji jednak zawadzało, prowadząc do stałego „uciekania” ze strukturalistycznie pojmowanej poetyki. Pamiętam, gdy na zajęciach mówił o Jakobsonowskim podziale na tropy metaforyczne i metonimiczne, zaraz podawał przykłady przekraczające i łączące te dwie oddzielne zasady. Bardzo nas, studentów, wtedy cieszyło, że coś się nie zgadzało, nie mieściło w ramach, łączyło nieoczekiwanie. Pokochaliśmy wtedy oksymoron.

Pamiętam - był jeszcze spektakl w Teatrze Ósmego Dnia - Jednym tchem, który oglądaliśmy „z zapartym tchem”. Ten teatr (legendarne Ósemki) i ten spektakl-bunt (sprzeciw wobec zniewolenia) określiły nasze przeżycie pokoleniowe.

Bieżący numer „Przestrzeni Teorii” poświęcamy Stanisławowi Barańczakowi. Wydajemy go celowo w przestrzeni „po micie” - oczyszczonej już z piętna okoliczności. Spektakl teatralny zszedł z afisza, projekcja filmu się zakończyła, nagroda została wręczona, mural raz w słońcu, raz w deszczu spokojnie trwa na betonowej ścianie Collegium Novum, pasażem w Collegium Maius przechodzą pośpiesznie studenci. I tylko, gdy przejeżdżam samochodem ku miastu, od strony katedry, czytam wiersz Jeżeli porcelana, to wytacznie taka, który - wypisany na ścianie domu stale porusza, który wdarł się poezją w środek zatłoczonego miasta, stojący w korkach ludzie - czytają!

Jest pewnym paradoksem, że we współczesnym świecie czytanie wierszy równocześnie zanika i powraca. Poezja, uznawana potocznie za niezrozumiałą i trudną, przeznaczoną dla wąskiej grupy odbiorców, zda- 
wać by się mogło nie wychodzi poza akademickie ramy. A jednak, intymność i jednostkowość lektury uzupełniane są coraz częściej czytaniem wspólnotowym, które łączy, zaciera granice profesji, pełnionych funkcji, światopoglądów i przekonań, umiejętności publicznych wystąpień.

Pamiętam - wieczorne czytanie wierszy Stanisława Barańczaka po śmierci Poety w hallu Collegium Maius UAM w Poznaniu zarówno przez Jego Magnificencję Rektora UAM, Prezydenta Miasta, profesorów, studentów, uczniów, aktorów, poetów, jak i wszystkich, którzy wiersze przynieśli i chcieli je głośno przeczytać. Gdy Poeta odchodzi, publiczność w akcie admiracji i tęsknoty za „spotkaniem autorskim”, którego już nigdy nie będzie, sama zaczyna czytać utwory (Jemu?, sobie?, Innym?). Można by jednak przewrotnie powiedzieć, że recytacje wierszy zawsze wpisywane były w „akademie ku czci” i zwykle oznaczały wtedy patos rozumiany potocznie jako sztuczność, podniosłość, wędzidło retoryki. Działo się tak dlatego, że starannie wyreżyserowane spektakle czciły przeważnie nieakceptowane, narzucane $\mathrm{z}$ zewnątrz lub skostniałe, zastygłe w szkolnej formule, normy i wartości. Coś się jednak zmieniło. Przyszliśmy spontanicznie, niekiedy i bez zaproszenia, na spotkanie z Barańczakiem poetą, z Jego poezją, która wybrzmiała autentycznym wielogłosem uczestników - nas, w akcie stwarzania ducha wolności i wiersza. Czytanie poezji wzmocniło natomiast patos rozumiany tu - zgodnie z sensem dramatycznym słowa - jako cierpienie i - pozostający w harmonii ze współczesną interpretacją kategorii wzniosłości pojmowanej jako niewyrażalności - akt uwewnętrznionych przeżyć. Wiersze Barańczaka, łamiące pancerze ubezwłasnowolnienia języka, zbudowały raz jeszcze autentyczną wspólnotę wolnych ludzi. Poczuliśmy się w tym akcie czytania poezji naprawdę blisko siebie, byliśmy ze Staszkiem razem.

Barańczak był zawsze, jak sam pisał i mówił w wywiadach „po stronie literatury nieufności i indywidualnej odpowiedzialności, a przeciw literaturze tworzącej czy podtrzymującej mity kolektywne [...] po stronie literatury wolności, a przeciw literaturze «ucieczki od wolności»"1.

Uczył, że literatura jest nieufnością. W czasach szarości i niejasności - określa wyraziste wybory, a na czas czarno-białych podziałów proponuje przyjrzenie się strefie szarości i niejednoznaczności. To bardzo cenne myślenie. W bezkształcie i zamgleniu szukać jasnych rozwiązań, w ostrych podziałach próbować znaleźć to, co niepewne i niejednoznaczne w ocenie. Mówił: „W sytuacji przeważającego rozmazania etycznych kryteriów wagi społecznej nabiera, a nieraz i wielkość artystyczną osiąga literatura przypominająca pewne proste a podstawowe prawdy [...], aby zwyczajnie przestać kłamać. W sytuacji natomiast, kiedy w społeczeń-

${ }^{1}$ S. Barańczak, Przekraczanie granic. Rozmowa z Dariuszem Tołczykiem, [w:] Zaufać nieufności. Osiem rozmów o sensie poezji 1990-1992, red. K. Biedrzycki, Kraków 1993, s. 87. 
stwie przeważa poczucie pewności kryteriów, wedle których jednych się sławi a innych potępia [...] wtedy zaczyna się, znowu przekornie, rola literatury, która komplikuje i utrudnia takie proste osądy, na nowo cieniuje szarością to, co zdążyło się zredukować do kontrastu czerni i bieli”2.

Cieniował słowa. Ostremu światłu dodawał cień. Literatura przecież jest nieufnością. Nieufnością, która ocala. Nieufnością, która strzeże, by nie weszły w krwiobieg społeczny efekty retoryki złej perswazji, żeby nie zmieniły się w nasz językowy „codzienny marsz”. Więc ,jednym tchem” czytajmy głośno te wiersze, które bronią przed wszelkim kłamstwem, zniekształcaniem pojęć, nieprawością etyczną. Może więc dziś szansą dla nas wszystkich jest nie tyle poetycki dialog, ile rozmowa poprzez poezję. Może więc jednak poezja ma moc performatywną ocalania i narodów, i ludzi?

Dyskretną ramę budują $\mathrm{w}$ numerze nawiązania do tak bardzo bliskiej Barańczakowi twórczości Wisławy Szymborskiej (od pierwszego tekstu zastępującego „radość pisania” „radością czytania”, przez rozmaite nawiązania, aluzje, tropy, światopoglądy pojawiające się w wielu artykułach, aż po przekłady włoskiej recepcji Poetki).

Tym razem w „Przestrzeniach Teorii” zamiast działu Rozprawy będą Interpretacje. Zaproponowałam Autorom napisanie interpretacji jednego utworu (wiersza, przekładu, prozy, dialogu). Teksty literaturoznawcze sąsiadują z lżejszymi esejami. Zamiast indywidualnych wspomnień w dziale Prezentacje pojawiają się zdjęcia. Zamiast ciągłej narracji - fragmenty, montaż obrazów, drobne komentarze. Każdy z nas ma własne wspomnienia o Staszku, każdy ma swoje obrazy. Są jednak młodzi czytelnicy, którzy Poety nie znali, nie mieli nigdy w ręku Jego książek, prawie rozpadających się już dziś, wydań z "drugiego obiegu” (o literaturze „bezdebitowej” mówią często literatura „bezdebiutowa”, bo zwrot „bez debiutu” jest zrozumiały, a „bez debitu” - to pojęcie niewyobrażalne... niby kto w dobie Internetu miałby im „zezwalać na druk”!? Ten pożółkły papier to tylko historia, dla nas jednak te zdjęcia okładek są jak Różewiczowska „kartka wydarta z dziennika”, jak Hubermanowska malarska smuga - „plama pamięci”.

Pamiętamy Ciebie, Staszku, pozostaniesz z nami na zawsze; nie w potędze mitu, ale w sile wiersza.

Anna Krajewska

Redakcja „Przestrzeni Teorii” dziękuje Marcinowi Kęszyckiemu z Teatru Ósmego Dnia za pomoc w opracowywaniu numeru. Podziękowania składamy również Profesorowi Andrzejowi P. Florkowskiemu i Joannie Helander za udostępnienie zdjęć.

2 Tamże, s. 88. 
Stanisław Barańczak, Poznań 1979. Fot. Joanna Helander

Stanisław Barańczak, Poznań 1994. Fot. Joanna Helander
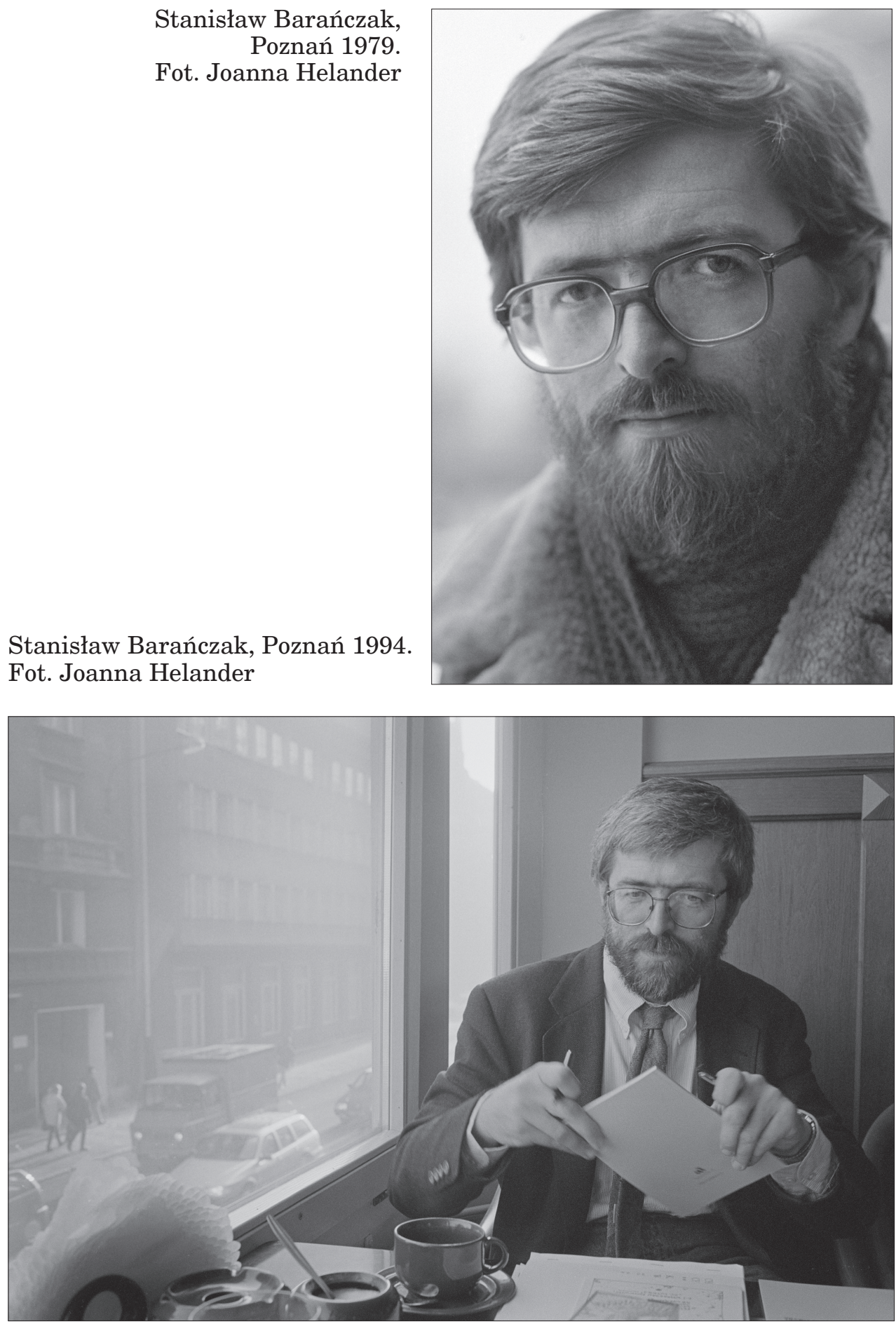


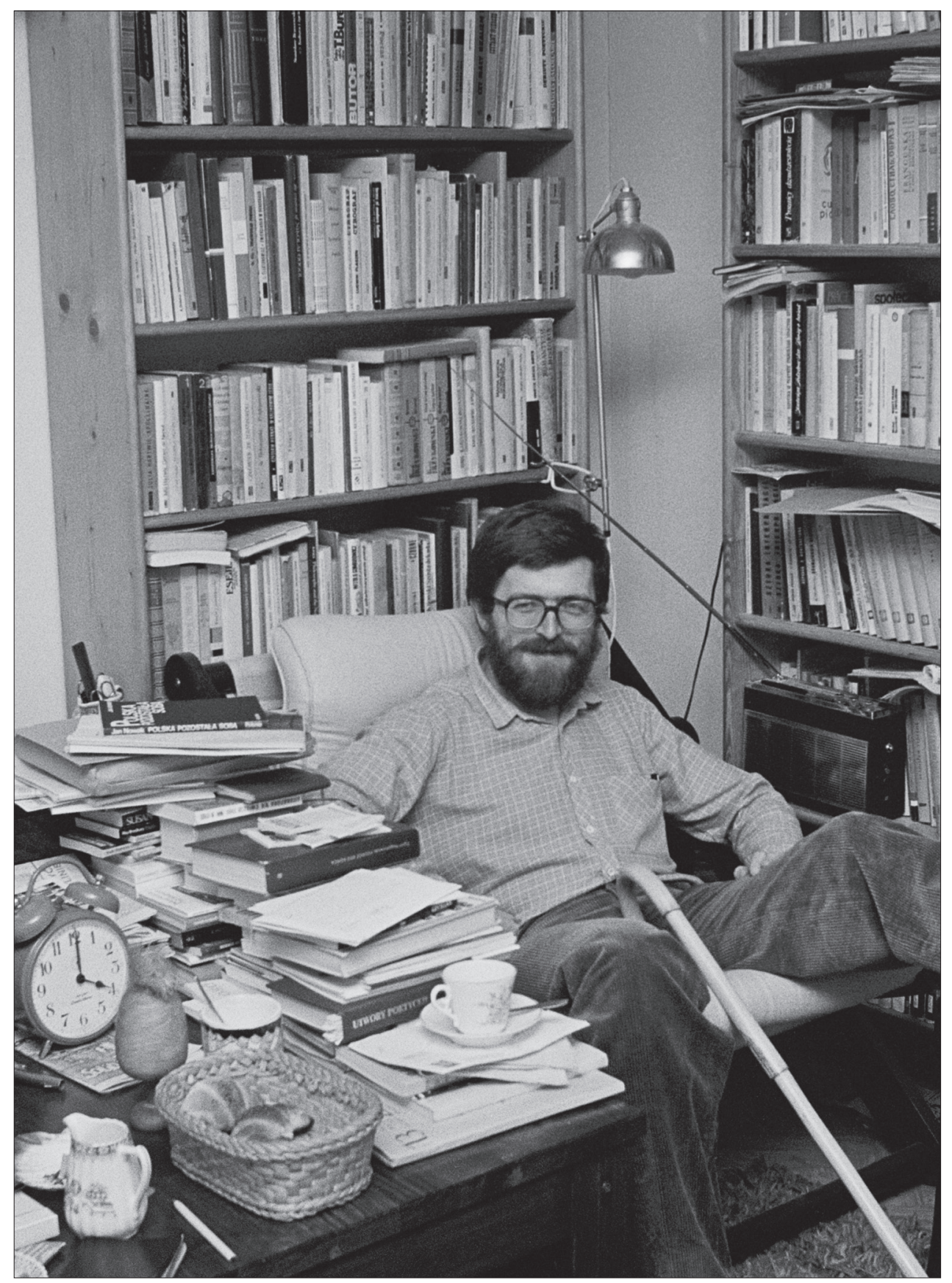

Stanisław Barańczak, Poznań 1980. Fot. Joanna Helander 


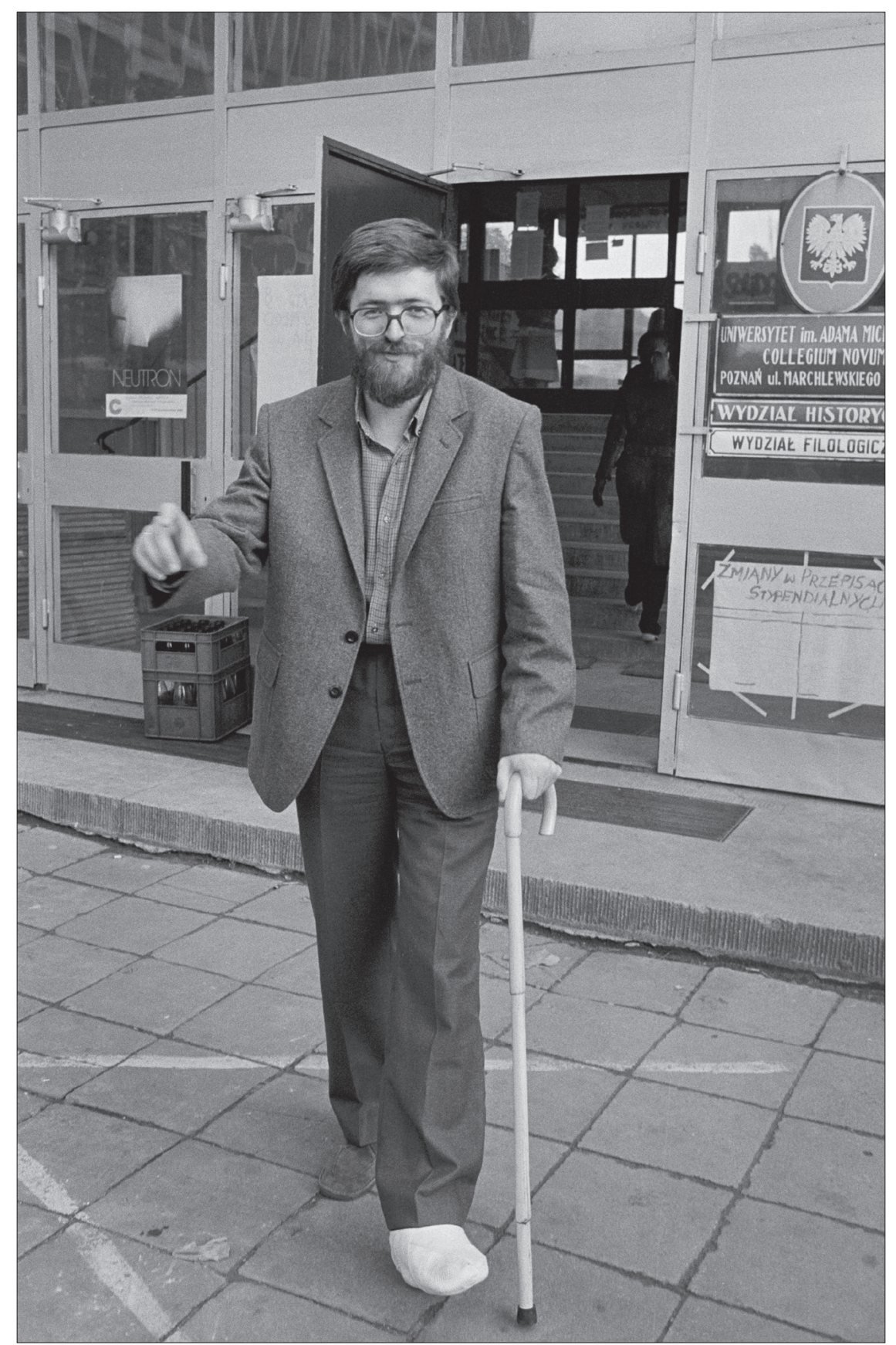

Stanisław Barańczak, Poznań 1980. Fot. Joanna Helander 


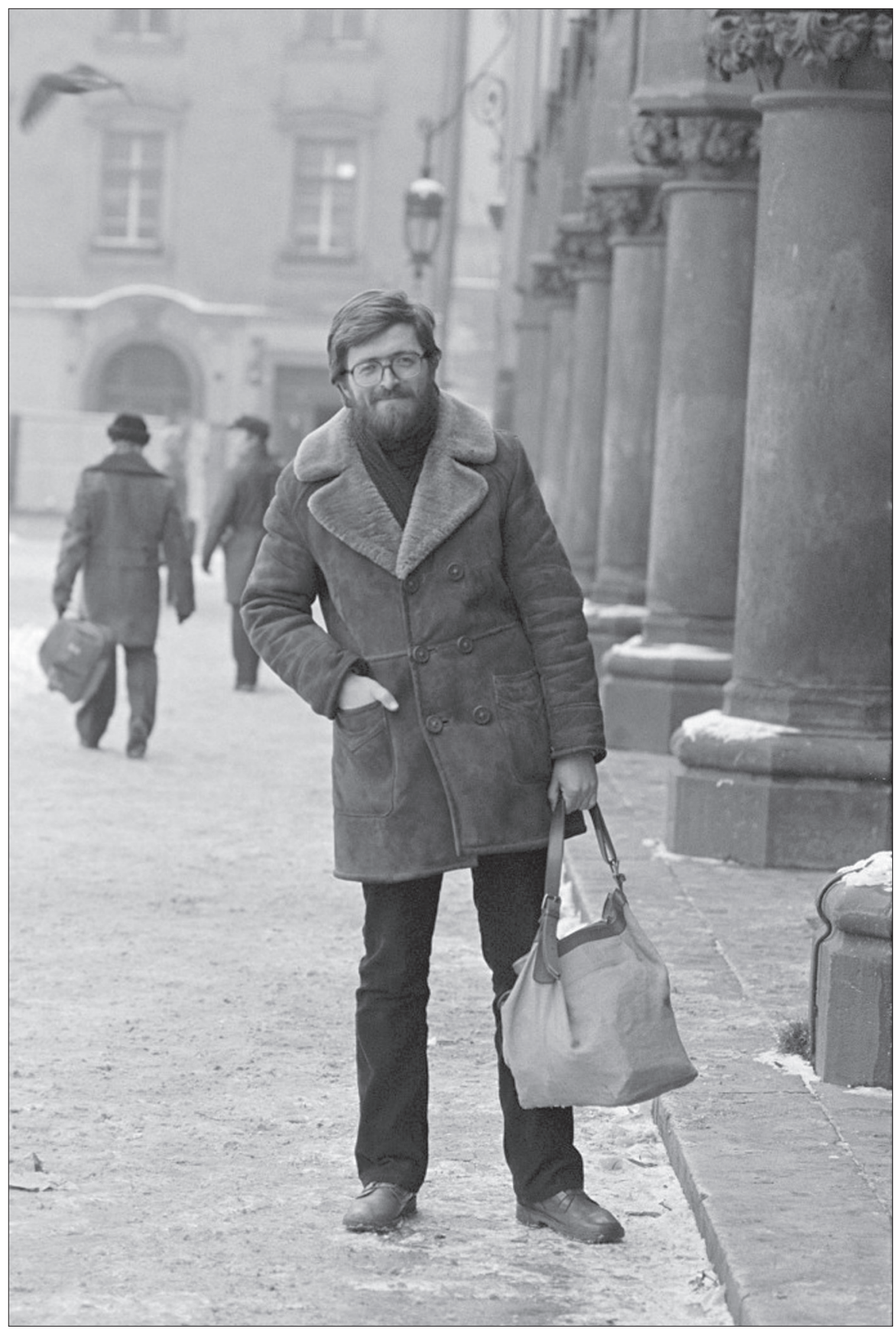

Stanisław Barańczak, Poznań. Fot. Joanna Helander 